\title{
Improved muscle function and quality after diet intervention with leucine-enriched whey and antioxidants in antioxidant deficient aged mice
}

\author{
Miriam van Dijk ${ }^{1}$, Francina J. Dijk ${ }^{1}$, Annelies Bunschoten ${ }^{2}$, Dorien A.M. van Dartel ${ }^{2}$, \\ Klaske van Norren ${ }^{3}$, Stephane Walrand ${ }^{4}$, Marion Jourdan ${ }^{1}$, Sjors Verlaan ${ }^{1}$ and \\ Yvette Luiking ${ }^{1}$ \\ ${ }^{1}$ Nutricia Research, Nutricia Advanced Medical Nutrition, Utrecht, The Netherlands \\ 2 Department of Animal Sciences, Human and Animal Physiology, Wageningen University, Wageningen, The Netherlands \\ ${ }^{3}$ Nutrition and Pharmacology, Wageningen University, Wageningen, The Netherlands \\ ${ }^{4}$ Unite de Nutrition Humaine, INRA-UdA, Clermont-Ferrand, France \\ Correspondence to: Miriam van Dijk, email: Miriam.vandijk@nutricia.com
}

Keywords: sarcopenia, skeletal muscle, fatigue, antioxidants, Gerotarget

Received: December 21, $2015 \quad$ Accepted: January 30,2016 Published: February 29, 2016

\section{ABSTRACT}

Antioxidant (AOX) deficiencies are commonly observed in older adults and oxidative stress has been suggested to contribute to sarcopenia. Here we investigate if 1) low levels of dietary antioxidants had a negative impact on parameters of muscle mass, function and quality, and 2) to study if nutritional interventions with AOX and/ or leucine-enriched whey protein could improve these muscle parameters in aged mice. 18-months-old mice were fed a casein-based antioxidant-deficient (lowox) diet or a casein-based control-diet (CTRL) for 7 months. During the last 3 months, lowoxmice were subjected to either: a) continued lowox, b) supplementation with vitamin $A / E$, Selenium and Zinc (AOX), C) substitution of casein with leucine-enriched whey protein (PROT) or d) a combination of both AOX and PROT (TOTAL). After 7 months lowox-mice displayed lower muscle strength and more muscle fatigue compared to CTRL. Compared to lowox-mice, PROT-mice showed improved muscle power, grip strength and less muscle fatigue. AOX-mice showed improved oxidative status, less muscle fatigue, improved grip strength and mitochondrial dynamics compared to lowox-mice. The TOTAL-mice showed the combined effects of both interventions compared to lowox-mice. In conclusion, nutritional intervention with AOX and/or leucine-enriched whey protein can play a role in improving muscle health in a AOXdeficient mouse model.

\section{INTRODUCTION}

During the ageing process, muscle mass, strength and function decline, defining sarcopenia [1]. Contributors to sarcopenia are multi-factorial: decreased levels of physical activity, increased levels of oxidative stress, pro-inflammatory status, endocrine changes, anabolic resistance, and inadequate nutrition [1]. In addition to muscle mass and strength, another determining factor of muscle function is muscle power. The definition of muscle power is the ability to perform muscular work per unit of time [2]. Muscle power is strongly associated with gait speed [3], balance [4] and functional status [5]. More importantly, muscle power has been found to be more relevant than muscle strength for many tasks of daily living $[5,6]$. The decline of muscle mass, strength and power suggests a progressive worsening of muscle quality during ageing or in other words the decreased capacity of the muscle to adapt to its environment [2].

One of the mechanisms that contributes to the decreased muscle mass and quality during ageing is an imbalance between muscle protein synthesis and degradation [7]. Elderly people have deficits, e.g. anabolic resistance [7-11], which hinder them from responding adequately to anabolic stimuli such as insulin, leucine or dietary protein [7]. Among the amino acids, leucine can stimulate muscle protein synthesis by improving activation of translation initiation [12] [13]. Studies in isolated 
rat muscles [14], in adult rats [15] and older adults [16] demonstrated that the muscle protein synthesis response can be increased by increasing leucine availability to the muscle. Whey protein, a fast digested and absorbed leucine-rich protein, has proven to be more effective in stimulating muscle protein synthesis in older adults than slow digested casein protein $[17,18]$. A leucine-enriched whey protein may, therefore, represent a nutritional strategy for limiting muscle protein loss during ageing.

Another underlying mechanism of impaired muscle quality in the elderly is an increase in oxidative stress [19-21]. Oxidative damage induced by oxidative stress increases during ageing $[22,23]$ and can induce alterations in DNA, lipids and proteins [24], resulting in a decrease in their biological function. This may contribute to reduced muscle protein synthesis and mitochondrial dysfunction. The maximal rate at which an individual consumes oxygen $\left(\mathrm{VO}_{2 \max }\right)$ declines with age, even after correcting for losses in lean mass [25]. These data suggest that the muscle mitochondrial function decreases as people age, which can be explained by impaired adaptive capacity of mitochondrial functioning [26]. Processes that are suggested to underlie this impaired adaptive capacity are decreased mitochondrial biogenesis, but also decreased mitochondrial quality control via lowered mitochondrial dynamics [27].

Bolstering the antioxidant defense mechanisms by supplementing the diet with antioxidants showed promising results in studies in ageing rats [28, 29]. Improved motor function and muscle protein metabolism were observed when a combination of vitamins $\mathrm{E}$ and $\mathrm{C}$ [28] or vitamins A, E with selenium and zinc was given. However, supplementation of vitamin $\mathrm{E}$ alone failed to attenuate oxidative damage in muscle of ageing mice [30] and only slightly attenuated an exercise-induced increase in muscle oxidative stress $[31,32]$. These first indications suggest that mitochondrial functioning can be improved via nutritional interventions. Therefore we chose to use a mixture of plural components with antioxidant properties, which may represent the best strategy to address oxidative stress. This is even more important since older people are at risk of being deficient in multiple antioxidants, i.e. vitamins A, E, C, Selenium and Zinc [33-36]. Moreover, low levels of these antioxidants have been associated with sarcopenia and disability [37-39].

From literature, it is known that aged mice display loss of muscle mass, strength and function during ageing $[40,41]$. Our previous study also showed that, compared to 10 month-old mice, normal aged 25 month-old mice have decreased plasma levels of vitamin $\mathrm{A}$ and $\mathrm{E}$ in combination with elevated levels of malondialdehyde (MDA, a marker for damage of lipid oxidation), indicating elevated oxidative stress levels in aged mice [42, 43] . The aim of the present study was two-fold. First, to determine in ageing mice the long-term effects of low dietary intake of vitamin A, E, selenium and zinc, all components with antioxidant properties [28, 29, 44-46], on muscle mass, strength, function and to mimic human ageing. In this model dietary deficiency was induced by decreasing intake of vitamin A, E, Selenium and Zinc to $25 \%$ of the daily recommended intake for rodents [47]. In this way we aimed to induce in a relatively short time interval effects on muscle parameters without completely eliminating the micro-nutrients from the diet. Secondly, this study aimed to determine the subsequent effects of dietary supplementation/ repletion with these antioxidants, or a diet replacing casein protein by leucine-enriched whey protein, or a combination of both on muscle mass, strength, function and quality. We hypothesized that aged mice on a diet low in antioxidant have more pronounced loss of muscle quality than aged mice on a control feed with standard anti-oxidant levels (AIN93M). Moreover, we tested whether the dietary interventions might improve muscle quality through improved muscle protein synthesis and/or mitochondrial dynamics [48]. Therefore we adjusted the algorithm introduced by Barbat-Artigas et al. to be applicable to mice [2].

\section{RESULTS}

\section{Effect of diet low in components with anti-oxidant properties compared to control aged mice}

\section{Oxidative status}

Lowox-mice did not show elevated levels of whole body oxidative stress compared to control mice at 22 months of age, as shown in Figure 3A for hepatic GSH and in Figure 3B for hepatic MDA. In the ageing process control mice had significantly higher whole body oxidative stress and lipid peroxidation, as reflected by decreasing liver GSH levels $(P<0.05)$ (Figure 3A) and increased MDA levels between 22 and 25 months $(P<0.05)$ (Figure 3B). Lowox-mice and control mice showed a similar pattern during ageing for GSH levels; however, MDA levels after 7 months of the lowox-diet were significantly higher in lowox than in control mice $(P<0.05)$. Plasma levels of vitamin $\mathrm{A}$ and $\mathrm{E}$ did not alter during ageing from 22 to 25 months, nor were they affected by the diet (Table $3)$. Hepatic levels of vitamin A also did not show any significant changes at 25 months of age, but vitamin $\mathrm{E}$ displayed a trend $(P=0.076)$ towards decreased levels in the lowox group $v s$. control.

\section{Body weight and composition}

No significant difference in body weight was observed between control and lowox-mice, as shown in Table 4. From 18 until 22 months of age, both groups showed a significant increase in body weight $(P<$ $0.0001)$, and thereafter, body weight was stable until 25 months of age. The control and lowox-mice did not show 


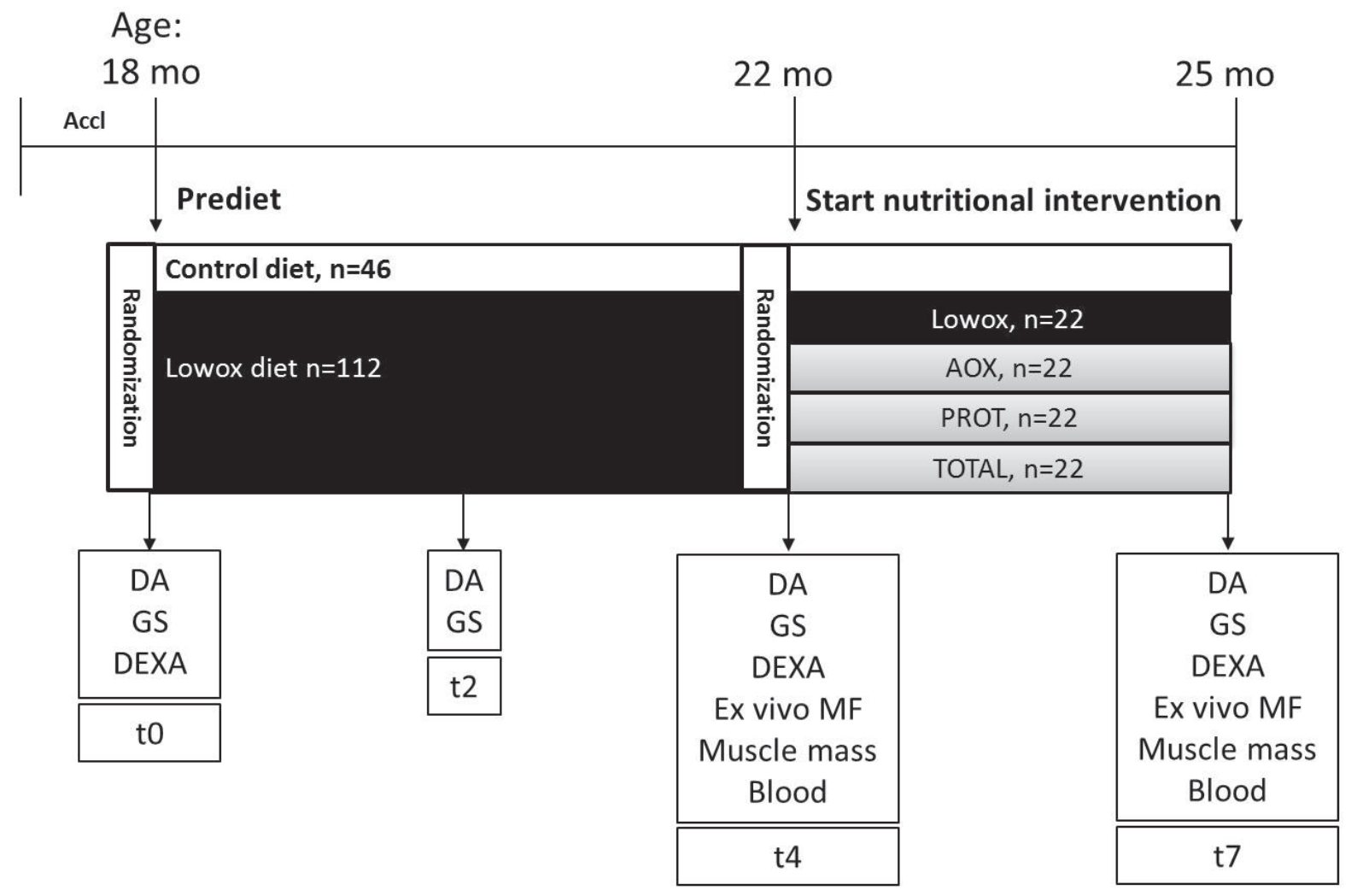

Figure 1: Experimental setup. Abbreviations mo: months, Ctrl: mice on control diet = AIN93-M (casein protein based), Lowox: mice on diet low in antioxidants (vitamin A, E, Se and Zn), AOX: mice on diet supplemented with vitamin A, E, Se and Zn, PROT: mice on diet where casein is replaced by leucine-enriched whey protein, TOTAL: mice on diet of combination of AOX and PROT, DA: daily activity measurements, GS: in vivo muscle grip strength measurements, DEXA: body composition analyses, and MF: ex vivo muscle function measurements.

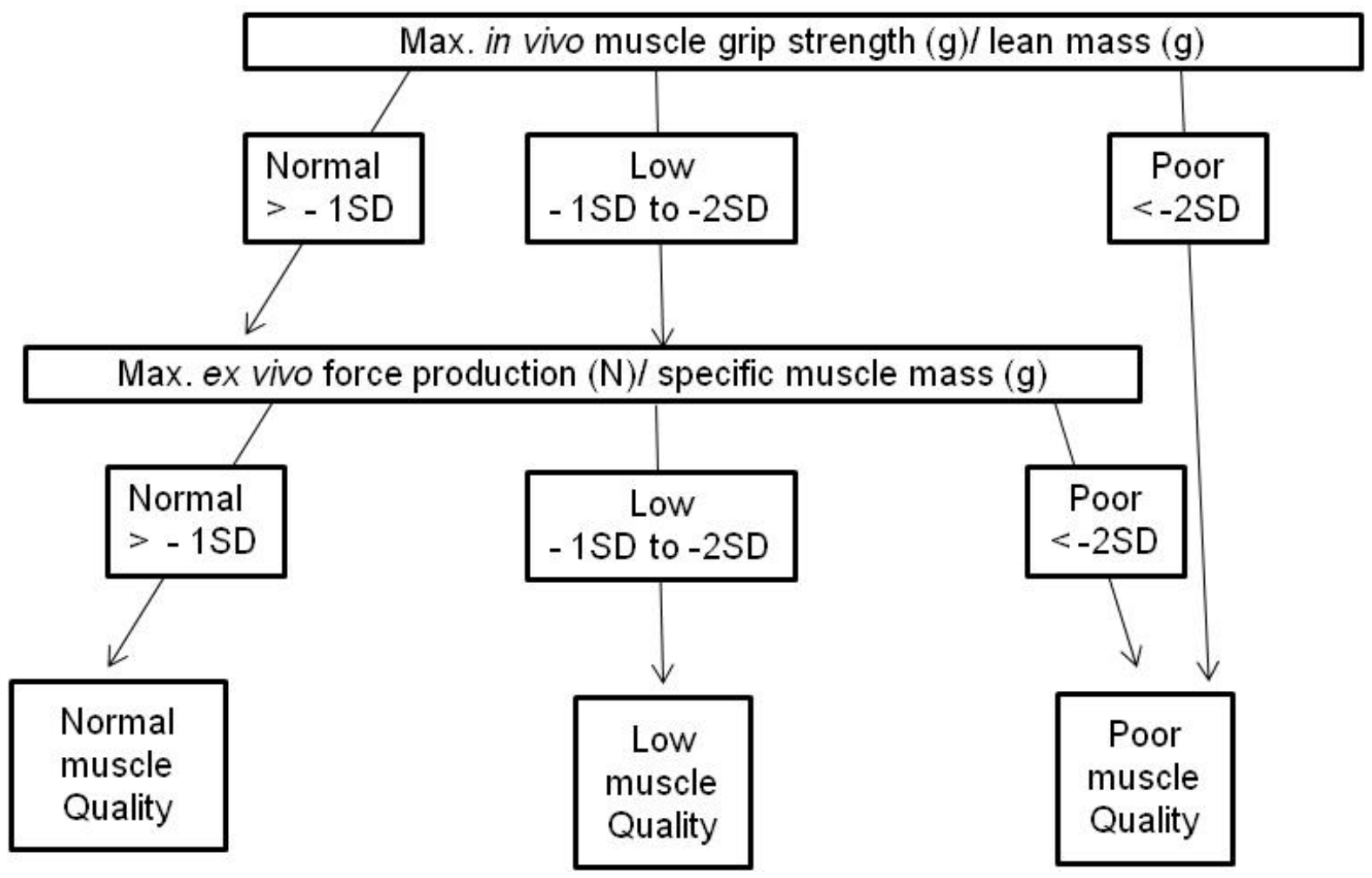

Figure 2: Modified algorithm to define muscle quality index in mice based on Barbat-Artigas et al. [2]. 


\section{Systemic oxidative status}
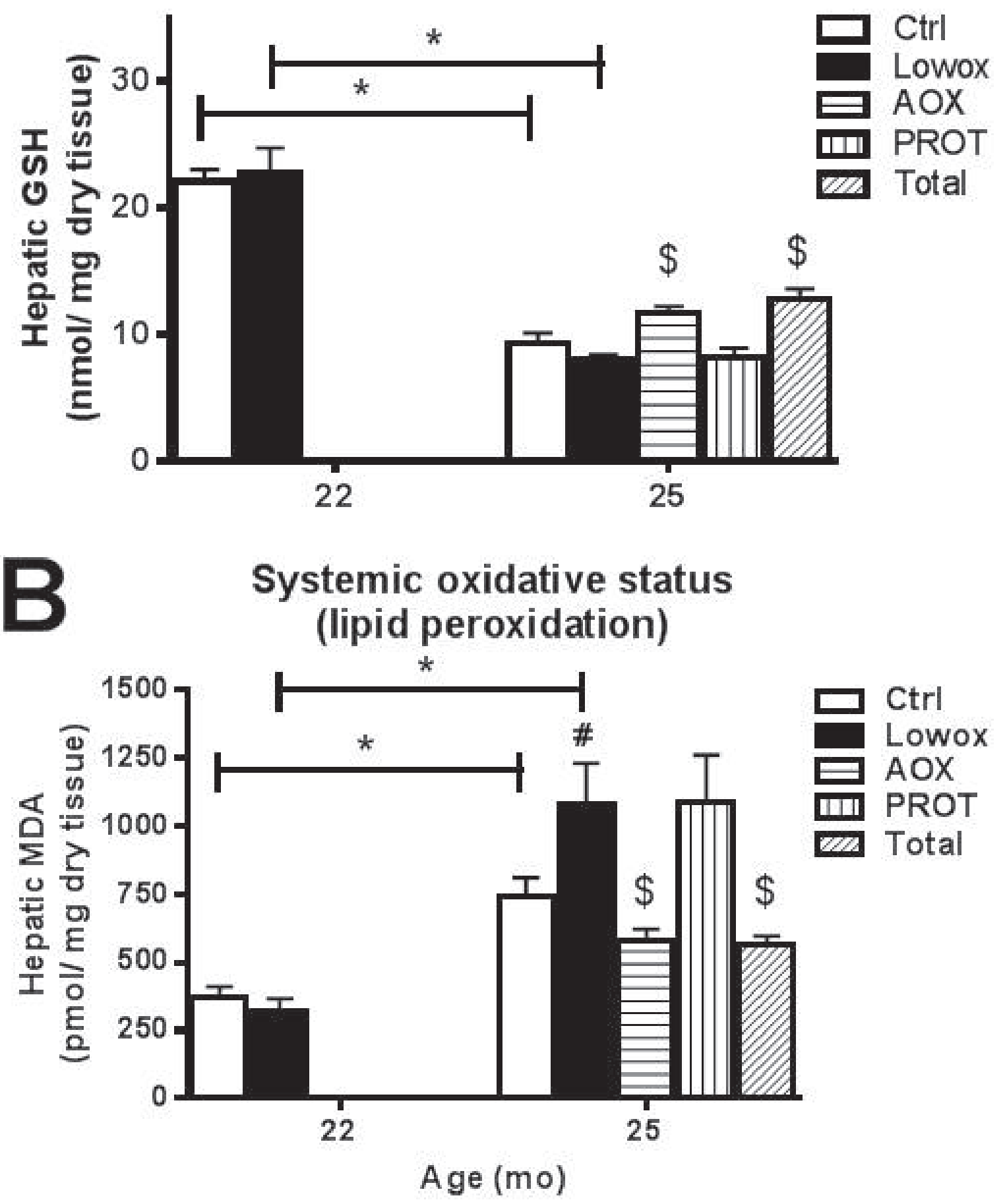

Figure 3: Oxidative stress. A. hepatic total GSH levels, and B. hepatic MDA levels. At t0 and t4: $\operatorname{ctrl} n=8$ and lowox $n=9$; at $\mathrm{t} 7: \mathrm{ctrl} n$ $=19$, lowox $n=18$, AOX $n=18$, PROT $n=14$ and TOTAL $n=17$. Statistically significant age effect, \# diet effect at corresponding time point, \$ nutritional intervention effect compared to lowox-diet at $\mathrm{t} 7$ (mixed model post hoc Sidak, $P<0.05$ ). 
Table 1: Composition of the intervention diets

\begin{tabular}{|c|c|c|c|c|c|}
\hline Diet name & CTRL & Lowox & AOX & PROT & TOTAL \\
\hline Ingredients & \multicolumn{5}{|c|}{$g / k g d r y$ matter } \\
\hline Cornstarch & 466 & 466 & 466 & 466 & 466 \\
\hline Dextrinized cornstarch & 155 & 155 & 155 & 155 & 155 \\
\hline Casein & 141.8 & 141.8 & 141.8 & - & - \\
\hline Whey & - & - & - & 136.1 & 136.1 \\
\hline Leucine $^{1}$ & 13 & 13 & 13 & 16.8 & 16.8 \\
\hline Sucrose & 100 & 100 & 100 & 100 & 100 \\
\hline Corn oil & 40 & 40 & 40 & 40 & 40 \\
\hline Fiber $^{2}$ & 50 & 50 & 50 & 50 & 50 \\
\hline Mineral mix $^{3}$ & 35 & 35 & 35 & 35 & 35 \\
\hline Selenium (mg/kg) & 0.150 & 0.0375 & 2 & 0.0375 & 2 \\
\hline Zinc (mg/kg) & 10 & 2.5 & 65 & 2.5 & 65 \\
\hline Vitamin mix $^{3}$ & 10 & 10 & 10 & 10 & 10 \\
\hline Vitamin A (IU/kg) & 2400 & 600 & 8000 & 600 & 8000 \\
\hline Vitamin E (IU/kg) & 20 & 5 & 500 & 5 & 500 \\
\hline Choline bitrate chloride & 2.3 & 2.3 & 2.3 & 2.3 & 2.3 \\
\hline tert-butylhydroquinone & 0.008 & 0.008 & 0.008 & 0.008 & 0.008 \\
\hline
\end{tabular}

The control diet is AIN93-M without the antioxidant L-cysteine added. The control and lowox diets were provided the first 4 months of the experiment. The lowox diet was based on the control diet, except for the vitamin and mineral mixes. For the last 3 months of the experiment the lowox group was divided in 4 groups: Lowox (continuation), AOX (antioxidant supplemented group), PROT (leucine-enriched whey protein substituted group) and TOTAL (combination of AOX and PROT strategy). All diets were equal in amounts of protein (124g), carbohydrates (674g), fat (41g) and kcal (3665) per kg dry matter.

1. Total leucine amount, from intact protein and free leucine; 2. Fiber source is cellulose; 3. AIN93-M mineral and vitamin $\operatorname{mix}[45]$

Table 2: Muscle quality criteria in aged mice

\begin{tabular}{|l|l|l|}
\hline Level & $\begin{array}{l}\text { In vivo max grip strength (g)/ lean } \\
\text { mass (g) }\end{array}$ & $\begin{array}{l}\text { Maximal force production (N)/ EDL } \\
\text { muscle mass (g) }\end{array}$ \\
\hline Normal $>1$ SD & $>0.96$ & $>3.24$ \\
\hline $1 \mathrm{SD} \geq$ Low $>2$ SD & $0.96 \geq X>1.92$ & $3.24 \geq X>6.48$ \\
\hline Poor $\leq 2 \mathrm{SD}$ & $\leq 1.92$ & $\leq 6.48$ \\
\hline
\end{tabular}

Normal levels derived from results of a previous experiment where muscle parameters of 10 months aged mice $(n=48)$ were analyzed. 
Table 3: Plasma levels of vitamin $A$ and $E$ at $\mathbf{t} 4$ (22 months of age) and $\mathbf{t} 7$ (25 months of age).

\begin{tabular}{|l|l|l|l|l|l|l|}
\hline & & \multicolumn{2}{|c|}{ Plasma } & \multicolumn{2}{c|}{ Liver } \\
\hline Groups & $\mathbf{n}$ & $\begin{array}{l}\text { Age } \\
(\mathbf{m o})\end{array}$ & $\begin{array}{l}\text { Vitamin A } \\
(\mu \mathrm{mol} / \mathbf{L})\end{array}$ & $\begin{array}{l}\text { Vitamin E } \\
(\mu \mathrm{mol} / \mathbf{L})\end{array}$ & $\begin{array}{l}\text { Vitamin A } \\
(\boldsymbol{\mu g} / \mathbf{g} \text { sample })\end{array}$ & $\begin{array}{l}\text { Vitamin E } \\
(\boldsymbol{\mu g} / \mathbf{g} \text { sample })\end{array}$ \\
\hline Control & 7 & 22 & $2.07 \pm 0.21$ & $6.10 \pm 0.47$ & $956 \pm 476$ & $26.2 \pm 5.90$ \\
\hline Lowox & 7 & 22 & $1.57 \pm 0.26$ & $6.99 \pm 0.41$ & $480 \pm 499$ & $9.80 \pm 1.80^{*}$ \\
\hline & & & & & & \\
\hline Control & 7 & 25 & $1.74 \pm 0.16$ & $6.39 \pm 0.71$ & $2913 \pm 285$ & $21.2 \pm 12.2$ \\
\hline Lowox & 9 & 25 & $1.92 \pm 0.13$ & $6.12 \pm 0.32$ & $1851 \pm 228$ & $5.50 \pm 0.89$ \\
\hline AOX & 9 & 25 & $1.77 \pm 0.07$ & $11.3 \pm 0.64 *$ & $7438 \pm 651 *$ & $147 \pm 51.5 *$ \\
\hline PROT & 8 & 25 & $1.83 \pm 0.22$ & $7.10 \pm 0.41$ & $1780 \pm 446$ & $9.86 \pm 4.18$ \\
\hline TOTAL & 8 & 25 & $2.12 \pm 0.10$ & $14.7 \pm 0.66^{*}$ & $8298 \pm 362^{*}$ & $373 \pm 138^{*}$ \\
\hline
\end{tabular}

* Statistical significant effect of diet aged matched control (mixed model with post hoc Sidak, $P<0.05$ )

a statistically significant difference in food consumption during the 7 months of the experiment (Table 4). The increase in body weight during the first 4 months of the diets for both groups can be explained by a significant increase of both lean $(P<0.05)$ and fat mass $(P<0.0001)$ (Figure 4A and 4B). Although body weight was not significantly altered after 22 months of age, control mice still showed significant increases in fat and lean mass from 22 to 25 months of age. In contrast, lowox-mice did not show an increase in lean mass from 22 to 25 months of age, but fat mass increased significantly $(P=0.047)$. The lowox-mice showed a significant lower lean mass and fat mass compared to control mice at 25 months of age ( $P=0.035$ and $P=0.003$, respectively). Surprisingly, all mice fed the lowox-diet for the first 4 months, showed a significantly higher bone mineral density compared to control mice at 25 months of age $(P=0.026$ for overall diet effect), regardless of the nutritional intervention received for the last 3 months (Figure 4C). No significant change was observed in bone mineral content (data not shown).

\section{Muscle strength, function and quality}

Figure 5A shows that both control and lowox-mice display a decline in maximal in vivo muscle strength from 22 to 25 months of age $(P<0.001)$. Lowox-mice already have significantly lower muscle strength at 22 compared to 18 months of age $(P=0.011)$ and compared to control mice of 22 months of age $(P<0.00001)$. Figure 5B shows the mean physical activity during the dark period for control and lowox-mice, and it clearly shows that activity decreases during ageing in both groups with no effect of the lowox-diet.

Ex vivo muscle function measurements of isolated EDL muscles at 22 (data not shown) and 25 months of age showed no significant difference in maximal force production between control and lowox-mice (Figure 5C) nor in force production during a moderate exercise protocol (Figure 5D). However, mice subjected to a diet low in antioxidants for 7 months showed significantly more muscle fatigue (i.e. a lower fatigue index) than control mice of the same age of 25 months $(P=0.003)$ (Figure 5E).

Muscle quality, defined with an algorithm (Figure 2) showed no significant differences between the control and lowox-mice (Figure 6).

\section{Mitochondrial dynamics}

Seven key genes involved in mitochondrial fusion and fission processes were analyzed: $M f n 1, M f n 2, D n m 1 l$, Fis 1, Mff, Mief1, and Mief2. To visualize the differences between the experimental groups, we applied a novel approach based on Principal Component Analysis (PCA). PCA showed that there was no significant difference between control and lowox-mice neither at 22 nor at 25 months of age and also no significant age effect. However, when both age groups were combined there was a trend $(P=0.079)$ that lowox-mice showed decreased levels of mitochondrial dynamics (Figure 7A). Mitochondrial density, i.e. gene expression levels of Tomm20, was not affected by a diet low in anti-oxidants at 25 months of age as shown in Figure 7E.

\section{Nutritional interventions in a mouse model with low dietary antioxidants}

\section{Oxidative status}

As shown in Figure 3A and 3B, mice supplemented with antioxidants (AOX and TOTAL group) had significantly higher hepatic GSH levels and lower MDA levels compared to their lowox counterparts $(P<0.05)$. Plasma levels of vitamin A did not show any statistical differences between groups, but plasma levels of vitamin E clearly demonstrated higher levels of the antioxidant in the supplemented AOX and TOTAL diets. Also hepatic levels of both vitamins A and E clearly increased after supplementation of AOX and TOTAL compared to lowox$\operatorname{diet}(P=0.038$, Table 3$)$. 

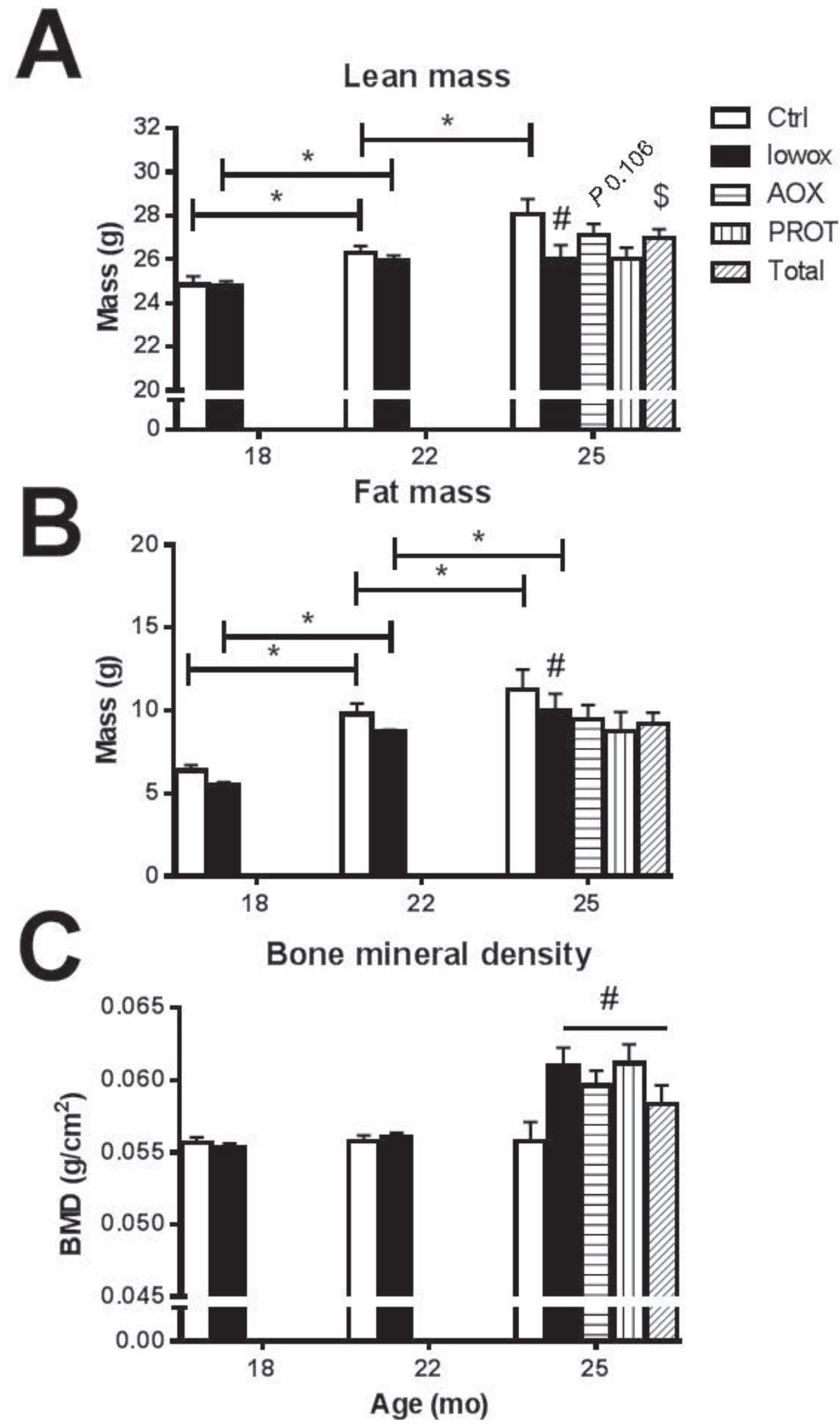

Figure 4: Body composition analyzed by DEXA. A. Lean mass; B. fat mass and C. bone mineral density. At t0 and t4: $\operatorname{ctrl} n=43$ and lowox $n=42$, at t7: $\operatorname{ctrl} n=19$, lowox $n=18$, AOX $n=18$, PROT $n=14$ and TOTAL $n=17$. Statistically significant age effect between 2 time points, \# significant effect of lowox compared to control diet at corresponding time point, \$ nutritional intervention effect compared to lowox-diet at 77 (mixed model with post hoc Sidak, $P<0.05$ ). 
A

Mean in vivo muscle strength

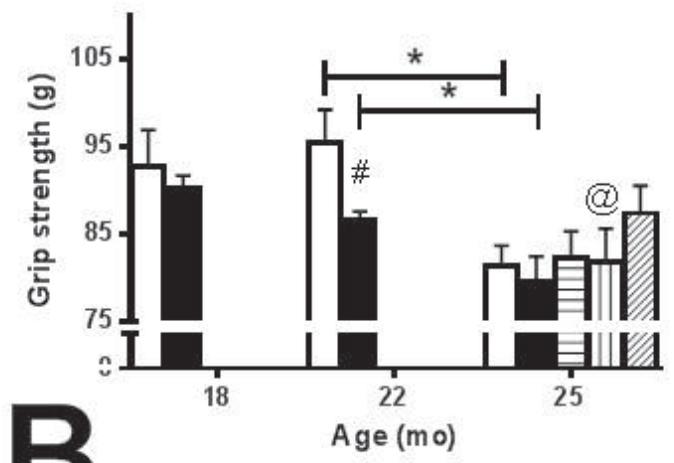

Maximal in vivo muscle strength
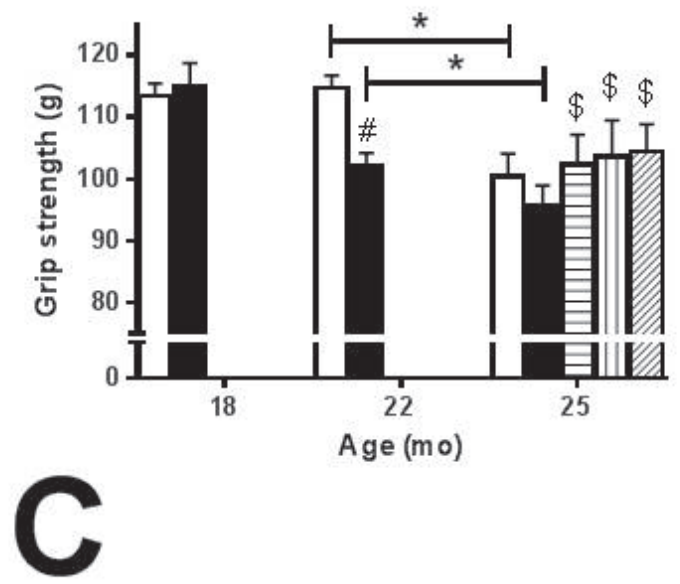

Mean activity dark period

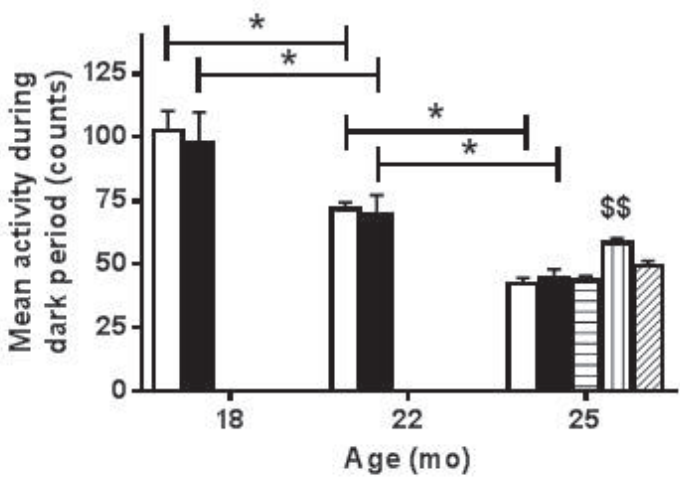

Force-Frequency relationship

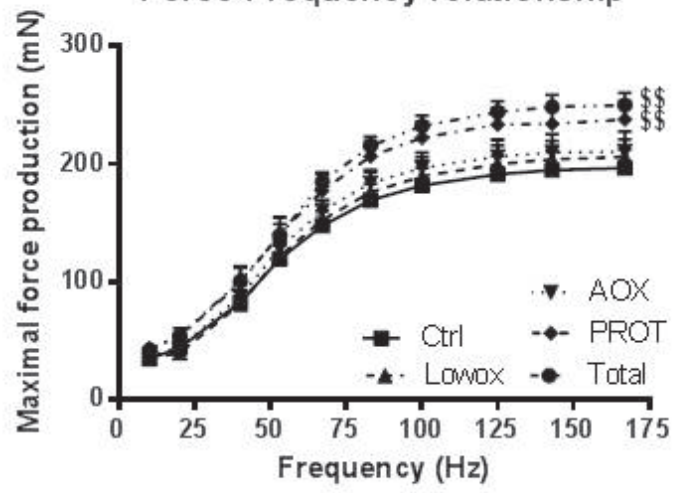

Total force production during first 40 contractions

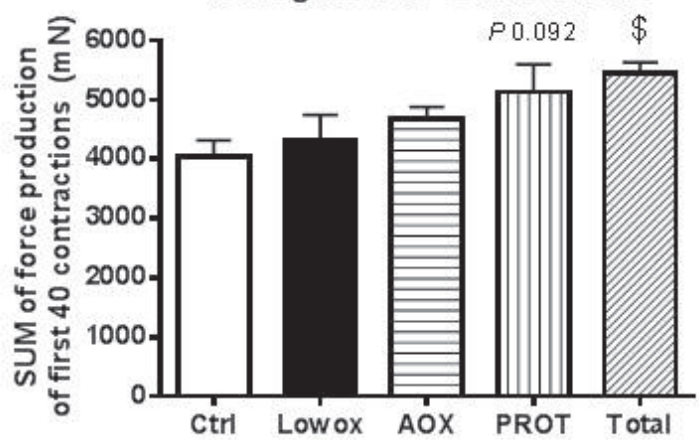

Muscle fatigue after moderate exercise protocol

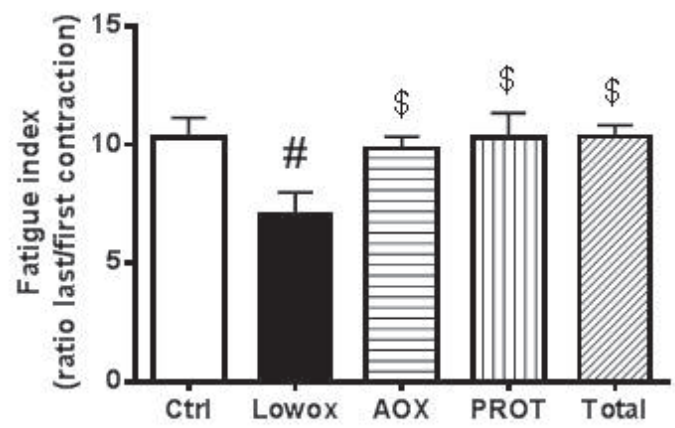

Figure 5: Muscle functionalities. A. Absolute maximal forelimb strength values. At t 0 and $\mathrm{t} 4$ : $\operatorname{ctrl} n=43$ and lowox $n=42$, at $\mathrm{t} 7: \operatorname{ctrl} n$ $=19$, lowox $n=18$, AOX $n=18$, PROT $n=14$ and TOTAL $n=17$. B. mean daily physical activity during dark (active) period. At t0, t4 and t7: $\operatorname{ctrl} n=10$, lowox $n=13$, AOX $n=10$, PROT $n=6$ and TOTAL $n=10$. C. Force-frequency relationship at t7, D. Total force production during a moderate exercise protocol of the first 40 contractions at $\mathrm{t} 7$ and $\mathbf{E}$. Muscle fatigue after a moderate exercise protocol at $\mathrm{t} 7$. For Figure 4D.-4F. Ctrl $n=16$, lowox $n=13$, AOX $n=15$, PROT $n=10$ and TOTAL $n=14 . *$ Statistically significant age effect between 2 time points, \# significant effect of lowox compared to control diet at corresponding time point, $\$$ nutritional intervention effect compared to lowox-diet at 17 and $\$ \$$ nutritional intervention effect compared to control diet at t7 (mixed model with post hoc Sidak, $P<0.05$ ). 
Table 4: Body weight, food intake and muscle mass.

\begin{tabular}{|l|l|l|l|l|l|l|l|l|l|}
\hline Group & $\mathbf{n}$ & $\begin{array}{l}\text { BW } \\
(\mathbf{g})\end{array}$ & $\begin{array}{l}\text { FI } \\
(\mathbf{g})\end{array}$ & $\begin{array}{l}\text { SUM } \\
(\mathbf{m g})\end{array}$ & $\begin{array}{l}\text { TA } \\
(\mathbf{m g})\end{array}$ & $\begin{array}{l}\text { EDL } \\
(\mathbf{m g})\end{array}$ & $\begin{array}{l}\text { SOL } \\
(\mathbf{m g})\end{array}$ & $\begin{array}{l}\text { PLANT } \\
(\mathbf{m g})\end{array}$ & $\begin{array}{l}\text { GM } \\
(\mathbf{m g})\end{array}$ \\
\hline \multicolumn{8}{|c|}{ Mean weights at start of experiment (pre-diet t0) } \\
\hline Ctrl & 41 & $33.9 \pm 0.5$ & $4.07 \pm 0.04$ & - & - & - & - & - & - \\
\hline Lowox & 94 & $32.7 \pm 1.2$ & $4.09 \pm 0.04$ & - & - & - & - & - & - \\
\hline \multicolumn{8}{|c|}{ Mean weights after 4 months of lowox diet (t4) } \\
\hline Ctrl & 16 & $39.9 \pm 0.8^{*}$ & $4.25 \pm 0.08$ & $481.6 \pm 13$ & $54.3 \pm 1.1$ & $11.8 \pm 0.3$ & $11.5 \pm 0.5$ & $18.6 \pm 0.6$ & $144.7 \pm 5.0$ \\
\hline Lowox & 16 & $38.3 \pm 1.2^{*}$ & $4.13 \pm 0.08$ & $495.2 \pm 8.0$ & $55.1 \pm 1.3$ & $12.3 \pm 0.3$ & $11.9 \pm 0.4$ & $18.9 \pm 0.4$ & $149.5 \pm 2.9$ \\
\hline \multicolumn{8}{|c|}{ Mean weights after additional 3 months of nutritional intervention (t7) } \\
\hline Ctrl & 17 & $39.4 \pm 2.9$ & $4.11 \pm 0.04$ & $482.2 \pm 10$ & $54.4 \pm 1.2$ & $12.6 \pm 0.3$ & $11.5 \pm 0.4$ & $19.1 \pm 0.7$ & $144.3 \pm 4.1$ \\
\hline Lowox & 13 & $40.0 \pm 1.4$ & $4.10 \pm 0.04$ & $477.6 \pm 12$ & $53.6 \pm 1.1$ & $12.1 \pm 0.3$ & $11.1 \pm 0.5$ & $18.6 \pm 0.7$ & $143.4 \pm 4.5$ \\
\hline AOX & 15 & $40.6 \pm 1.1$ & $4.15 \pm 0.06$ & $464.9 \pm 9.0$ & $52.8 \pm 1.4$ & $12.3 \pm 0.3$ & $10.7 \pm 0.4$ & $17.7 \pm 0.5$ & $138.9 \pm 3.5$ \\
\hline PROT & 13 & $38.3 \pm 1.4$ & $4.15 \pm 0.06$ & $451.4 \pm 10$ & $51.9 \pm 1.1$ & $12.1 \pm 0.3$ & $10.5 \pm 0.3$ & $18.1 \pm 0.4$ & $133.1 \pm 3.8$ \\
\hline TOTAL & 16 & $40.1 \pm 1.0$ & $4.12 \pm 0.06$ & $466.6 \pm 5.0$ & $55.2 \pm 0.9$ & $12.6 \pm 0.3$ & $10.8 \pm 0.3$ & $18.1 \pm 0.5$ & $136.5 \pm 1.8$ \\
\hline
\end{tabular}

* Statistically significant age effect on BW (no diet effect) from t0 (18 months of age) to t4 (22 months of age) (repeated measurements with post hoc Sidak, $\mathrm{P}<0.05$ ); no diet/age effects on muscle mass present (mixed model analyzes with post hoc Sidak, $\mathrm{P}<0.05$ ). Abbreviations: $\mathrm{BW}=$ body weight, $\mathrm{FI}=$ food intake, $\mathrm{SUM}=$ sum of hind limb of absolute muscle mass, $\mathrm{TA}=$ tibialis anterior muscle, $\mathrm{EDL}=$ extensor digitorum longus muscle, $\mathrm{SOL}=$ soleus muscle, $\mathrm{PLANT}=$ plantaris muscle, $\mathrm{GM}=$ gastrocnemius muscle, $\mathrm{Ctrl}=$ control mice, Lowox $=$ mice on diet low in antioxidants, $\mathrm{AOX}=$ antioxidant supplemented group, PROT=leucine-enriched whey protein substituted group, TOTAL=combination of AOX and PROT strategy.

\section{Body weight and composition}

As Table 4 shows, no difference in body weight and food intake was observed between the 3 interventions compared to the lowox-mice. Lean mass was not significantly different in the AOX $(P=0.106)$ and PROT $(P=0.289)$ groups compared to lowox-mice. However, TOTAL-mice showed a significantly higher lean mass compared to lowox-mice (Figure 4A, $P=0.031$ ). This effect on lean mass was not caused by an increase in muscle mass (Table 4) nor liver mass (data not shown). There was no difference in fat mass in the AOX, PROT and TOTAL group compared to lowox-mice (Figure
4B). The bone mineral density of the three nutritional interventions did not differ compared with the lowox group, and, similar to the lowox-mice, bone mineral density was higher compared to normal ageing mice at 25 months of age (Figure 4C, overall diet effect at 25 months of age $P=0.005$ ).

\section{Muscle strength, function and quality}

As shown in Figure 5A, all interventions resulted in significantly higher maximal muscle strength at 25 months of age, compared with the lowox group (AOX: $P=0.007$, PROT: $P=0.020$ and TOTAL: $P=0.019$, marked with $\$)$. The age-induced decline in physical activity during the

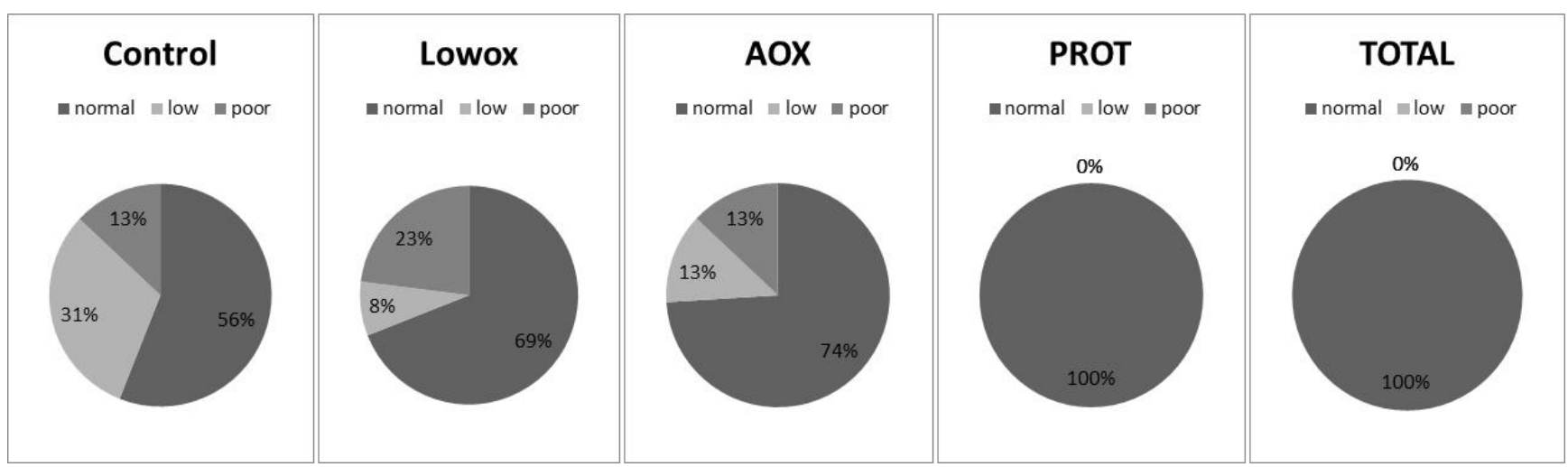

Figure 6: Muscle quality index. Data was calculated as maximal in vivo grip strength divided by lean mass and was categorized as normal ( $>-1 \mathrm{SD})$, low (-1SD to -2SD) and poor ( <-2SD). SD was calculated from a young reference population and cut off values were: $>3.58(=1 \mathrm{SD})>2.62(=2 \mathrm{SD})$. The next quality step was calculated as maximal ex vivo force production divided by EDL muscle mass and was categorized as well. Cut off values were: $>13.77(=1 \mathrm{SD})>10.53(=2 \mathrm{SD})$. Statistical analyses were done using Fisher's exact test. There was a trend for improved muscle quality for the PROT group compared to the lowox group $(P=0.07)$ and the TOTAL group had significantly better muscle quality compared to the lowox group $(P=0.004)$. 
dark period was significantly slowed down in the PROT group $(P=0.012)$, but not in the AOX or TOTAL group compared to lowox-mice at 25 months of age (Figure 5B). The physical activity level in the PROT group was higher than in normal ageing control mice at 25 months of age $(P=0.025)$.

During force-frequency relationship measurements of isolated EDL muscle, mice of the PROT and TOTAL group produced significantly higher maximal force than lowox-mice $(P=0.011$ and $P=0.008$ for PROT and TOTAL, respectively) and compared to control mice of the same age, as shown in Figure 5C. Additionally, during an exercise protocol, TOTAL-mice can produce significantly more force in the beginning of the exercise protocol than the other intervention groups and the lowoxmice, suggesting that these mice have more muscle power (Figure 5D). The PROT-mice showed a trend toward higher force production $(P=0.092 \mathrm{vs}$. lowoxmice). In contrast to the lowox-mice that show significant muscle fatigue at 25 months of age $(P=0.003)$, all three intervention groups were significantly less fatigued and had a fatigue index similar to the natural ageing control
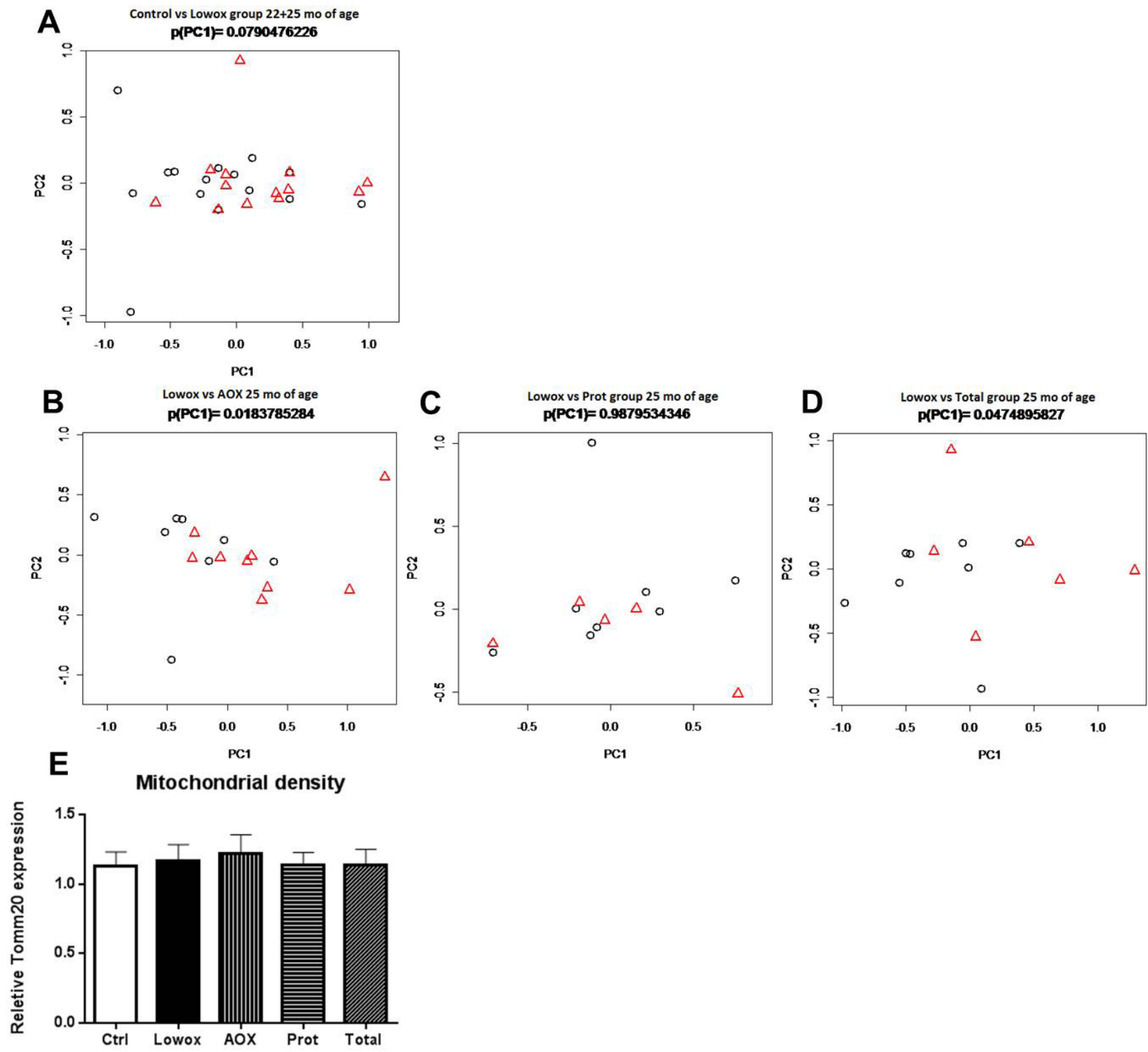

Figure 7: Mitochondrial dynamics. PCA-based modulation of mitochondrial dynamics using all seven mitochondrial dynamicsrelated genes at age $t=25$ months between respectively AOX A. PROT B. TOTAL C. compared to lowox reference group. Gene PCAvalues of the mitochondrial dynamics gene set in EDL of Lowox-fed animals are represented by black circles, and experimental groups (AOX, PROT, TOTAL) are represented by red triangles D. PCA-based modulation of mitochondrial dynamics using all seven mitochondrial dynamics-related genes at age $t=22+25$ months between control- and lowox-diet. Gene PCA-values of the mitochondrial dynamics gene set in EDL of Control-fed animals are represented by circles, and lowox are represented by triangles. E. gene expression of Tomm20, a marker of mitochondrial density. 
group $(P=0.012$, Figure 5E).

Muscle quality was similar between lowox and AOX-mice at 25 months of age, but was significantly improved in the TOTAL group compared to the lowoxmice $(P=0.004)$. The PROT group showed a trend towards improved muscle quality $(P=0.07$, Figure 6$)$.

\section{Mitochondrial dynamics}

Evaluation on the whole process level clearly revealed that the mitochondrial dynamics gene set of 7 genes was significantly regulated in both the AOX group directly $(P=0.018)$ group (Figure 7B), as well as in the TOTAL group directly $(P=0.048$, Figure 7D) group, compared to reference group (Lowox-mice). Gene expression levels of Tomm20, a marker for mitochondrial density, were similar between any of the groups (Figure 7E).

\section{DISCUSSION}

This study clearly demonstrates the occurrence of lower maximal muscle strength and more muscle fatigue when mice were fed a diet low in antioxidants vitamin A, vitamin E, Selenium and Zinc (lowox-mice) compared to control mice of the same age. A (tendency towards) less efficient mitochondrial functioning may underlie these observations. In the present study, we showed that the impaired muscle quality linked to poor antioxidant intake during ageing can be improved by nutritional intervention in which dietary casein protein is substituted with a leucine-enriched whey protein source. This intervention also resulted in greater muscle force and maximal muscle grip strength and less muscle fatigue with advanced age. When lowox-mice were supplemented with elevated levels of the specific antioxidant mixture, the general oxidative status of the mice clearly improved, along with less muscle fatigue and improved maximal muscle grip strength. An improved mitochondrial function via more efficient mitochondrial dynamics could underlie these effects of antioxidant supplementation. A combination of the two different dietary strategies did not result in a synergistic effect, but showed the combined effects of both interventions with an improved muscle quality index, less muscle fatigue, improved muscle power and maximal grip strength. To our knowledge, a direct link between positive modulation of mitochondrial dynamics and dietary supplemented components with anti-oxidants properties has not been demonstrated so far. Here, we show that dietary antioxidant intervention regulates mitochondrial dynamics on the process of gene expression level, which is an important first indication that targeting mitochondrial dynamics contributes to improving muscle function. Moreover, the data provide evidence for improved clinically relevant parameters such as fatigue, grip strength, muscle power and muscle quality by adapting the dietary protein source without changing the amount of daily dietary protein intake.

The level of antioxidants in the diet low in antioxidants was $25 \%$ of the advised daily intake of vitamin A, E, Selenium and Zinc for rodents [47]. Compared with the high levels in AIN-93-M of these vitamins and minerals, which exceed the advised daily intake, the lowox-diet seems more representative of the human situation where deficiencies in micronutrients in older individuals are common [33-36]. The antioxidant levels in the lowox-diet were viable and achievable for the aged mice: their well-being was monitored daily with extra attention for weight loss, food intake and activity. Plasma and liver levels of vitamin A and E were not changed in the antioxidant deficient diet. This suggests that other mechanisms may compensate for the lower dietary intake or that other markers should be analyzed like other isoforms of the vitamins or enzymes involved in the corresponding metabolic pathways. After 7 months, the compensatory mechanism, however, seems compromised and oxidative stress increased further compared to the normal aging levels, as shown by an elevated level of the oxidative stress marker MDA in lowox-mice. This specific diet low in antioxidants did not significantly affect body weight compared to control mice, but it did affect body composition. The lowox-mice had less lean and fat mass after 7 months of the diet than control mice, but without any impact on skeletal muscle mass of the lower extremities. It is remarkable that all animals that received the lowox-diet during the first 4 months had higher BMD at 25 months of age, independent of the nutritional intervention thereafter and with no correlation to physical activity. The underlying mechanism and biological relevancy of this increased BMD are not clear.

Although muscle mass of the lower extremities did not differ between control and lowox-mice, the muscle strength of the upper extremities was significantly less in the lowox-mice, which was already apparent at 22 months of age. This may be similar to humans, who also display an earlier decline in muscle strength during ageing than muscle mass with a negative impact on activities of daily living $[2,40,49]$. The diet low in antioxidants did not affect physical activity in mice, indicating that the well-being of the lowox-mice was likely not impacted. The present study is unique in its experimental design to correlate long-term dietary antioxidant deficiency with increased muscle fatigue. A trend towards decreased mitochondrial dynamics in lowox-mice may contribute to this phenotype. Finally, muscle quality was not different between lowox and control mice at 25 months of age. In both groups, up to one third had a low or poor muscle quality, with a slightly higher number of mice with a poor quality in the lowox group.

The nutritional intervention had no influence on the amount of food intake. Antioxidants supplementation clearly improved the oxidative status of the mice as shown by reduced MDA levels and increased GSH levels, 
without any impact on body composition. These results are in line with previous studies in non-antioxidant deficient rodents where different combinations of antioxidants were supplemented [28, 50-52]. Maximal muscle grip strength and muscle fatigue after an exercise protocol were restored to age-control level. However, muscle quality index did not show any improvements. Mosoni et al. showed that the oxidative status was improved by antioxidant supplementation in aged rats, leading to a better oxidative status of other organs, like liver, spleen and heart [29]. Our data confirm this finding by showing an improved oxidative status of the liver. This improved oxidative liver status is also reflected in improved muscle function in a previous study in rats [52]. Because we used a combination of antioxidants, we cannot pinpoint the observed effect to one specific antioxidant. To further elucidate the mechanism by which antioxidants impact fitness, genes involved in mitochondrial dynamics were analyzed. PCA analyses demonstrated improved mitochondrial dynamics when supplemented with antioxidants, with no effect on mitochondrial density. Our results are in line with research of Lee et al. [53]; they state that mitochondrial homeostasis affects muscle fatigue by decreased Mfn1/2 expression. Another clinical study showed that in healthy, elderly men mitochondrial respiration is correlated to muscle fatigability [25]. Again another study demonstrated that mitochondrial biogenesis is involved in exercise response of healthy, elderly men [54], but no diet interventions were included. Research of Mohamed et al. in old mice showed that with increased skeletal muscle fatigue, SIRT-1 is down-regulated, leading to less mitochondrial control [55]. Therefore, it is plausible that mitochondria play a role in muscle fatigue and may be influenced by antioxidants.

Many different studies have used dietary whey protein in elderly individuals, rodents or men [16, 18, 25, 56-58]. Replacing casein protein with whey protein in the diet improved maximal muscle grip strength, muscle force production, resistance to fatigue, muscle power in the beginning of an exercise protocol and higher activity scores, without impacting muscle mass. Since only the protein source was replaced in the PROT and TOTAL groups (leucine-enriched whey instead of casein protein, resulting in higher dietary leucine levels of $16.8 \mathrm{vs} .13 .0$ $\mathrm{g} / \mathrm{kg}$ ) with no change in the protein quantity, this suggests that the protein source is important for muscle quality. Vianna et al. demonstrated that long-term leucine-enriched casein supplementation $(29.3 \mathrm{~g} / \mathrm{kg})$ reduces fat mass gain without changing body protein status in ageing rats [59]. In this study, we did not find differences in body composition in the PROT group. This might be due to the difference in ageing process of mice vs. rats. Rats increase in body weight, mainly fat mass, throughout their lives [60], while body weight of mice stabilizes and subsequently decreases during ageing [61]. Norton et al. [15] demonstrated that dietary leucine content is a critical factor in stimulating postprandial muscle protein synthesis (MPS). However, we cannot exclude that MPS was frequently stimulated throughout the feeding period by higher levels of leucine in the diet. Even though muscle mass was not affected, a higher protein turnover could still have occurred, leading to improved (trend $P=0.07$ ) muscle quality. Another hypothesis tested by Kanda et al. [57] was that dietary whey protein increases glycogen levels in muscle, leading to less muscle fatigue [62]. It has also been reported that depletion of muscle glycogen stores is associated with fatigue during endurance exercise [63, 64]. We could, however, not confirm this hypothesis as we observed no dietary effect on muscle glycogen levels (data not shown).

A combination of both nutritional strategies did not have synergistic effects. However, supplementing with only AOX or replacing the protein source by leucineenriched whey protein in the PROT group did not show any effects on lean mass, while a combination of both significantly increased whole body lean mass. The AOX group showed less fatigue, likely through improved efficiency of mitochondrial dynamics; this was also applicable for the TOTAL group and therefore seems attributed to the antioxidant supplementation. The PROT group showed improved muscle strength and power, which was also demonstrated in the TOTAL group, with the addition that the muscle quality index was significantly increased in the TOTAL group (and only tended to improve in the PROT group). This suggests a benefit of the leucine-enriched whey protein source. These results support the hypothesis that both nutritional strategies contribute to an improved muscle quality, but likely act via different mechanisms.

In conclusion, the present findings show that a diet low in antioxidants leads to lower muscle strength, more muscle fatigue after an exercise challenge and to more oxidative stress without affecting skeletal muscle mass in mature mice. The negative impact of antioxidant deficiency could be prevented by supplementation of components with antioxidant properties. Supplementation of these components improves the oxidative status and also improves fatigue, which likely occurs via improved mitochondrial dynamics. Nutritional intervention with leucine-enriched whey protein can play a role in maintaining and improving muscle power and quality in aged mice with antioxidant deficiency. More importantly, we have demonstrated that supplementation of antioxidants in combination with a diet containing leucine-enriched whey protein is an effective and optimal strategy to improve general state of fitness and muscle quality in aged antioxidant deficient mice. These findings are also relevant for human aging, especially the elderly and frail or sarcopenic population that often suffers from antioxidant deficiencies, increased oxidative stress and loss of muscle quality. Therefore, clinical intervention studies in sarcopenic or frail older adults with antioxidant deficiencies are needed to confirm the observed effects on 
muscle health of antioxidants and leucine-enriched whey protein supplementation.

\section{MATERIALS AND METHODS}

\section{Animals}

Male C57/BL6J mice of 18 months of age were obtained from Janvier Labs (Saint Berthevin, France). Animals were individually housed in a climate-controlled room (12:12 dark-light cycle with a constant room temperature of $21 \pm 1^{\circ} \mathrm{C}$ ). Mice were fed ad libitum a standard diet (AIN-93-M) and had free access to tap water. All diets were provided by Research Diets Services (Wijk bij Duurstede, the Netherlands). All experimental procedures were approved by the Animal Ethical Committee (DEC consult, Bilthoven, the Netherlands). After the acclimatization period, mice were randomized on body weight in two different groups. The mean body weight of the two different groups did not deviate more than $5 \%$ of the overall mean body weight. One group received AIN-93-M (control diet, ageing control group, $n=33)$ and the other group $(n=133)$ received a diet that was lower to $25 \%$ of the daily recommended intake of lab animals (see Table 1) [47] for vitamin A (retinol), vitamin $\mathrm{E}$ ( $\alpha$-tocopherol), selenium and zinc (from now on called lowox-diet). After 4 months, lowox-mice were randomized again on body weight and lean mass. Then the lowox-mice were randomly divided into the different nutritional intervention groups with no greater deviation than $5 \%$ from the overall lowox group mean for body weight and lean mass ( $n=17$ per group). For a period of 3 months, one group continued with the lowox-diet, the second group was supplemented with higher doses than the control group of vitamin A (3x), vitamin E (25x), selenium (13x) and zinc (6.5x) [29] (called AOX), in the third group the casein protein in the diet was replaced by whey protein with additional leucine (called PROT) and the final group received a combination of the diet of groups two and three (called TOTAL). Body weight and food intake were determined twice a week. Mean total food intake during the total experimental period of 7 months was calculated as well as daily food consumption. For a schematic overview of the experimental setup, see Figure 1. During the total duration of the experiment mice were carefully observed for symptoms of general malaise or signs of moribund conditions. Mice were sacrificed by block randomization at 22 or 25 months of age by cardiac puncture under total isoflurane anesthesia (isoflurane/ $\mathrm{N}_{2} \mathrm{O} / \mathrm{O}_{2}$ ), the skeletal muscles from the hind limb (tibialis anterior, extensor digitorum longus (EDL), soleus, plantaris and gastrocnemius muscle) and the liver were dissected, weighted and stored at $-80^{\circ} \mathrm{C}$ until further use.

\section{Daily activity}

During the acclimatization period daily activity was measured for 1 week as normalization. Subsequently, daily activity was measured at the start of the experiment, after 4 months and at the end of the experiment on a subgroup of animals only due to practical limitations ( $n=$ $16 /$ group). Physical activity was monitored continuously (24h) for 7 days using activity sensors (dual technology detector DUO 240, Visonic; adapted by R. Visser, NIN, Amsterdam, The Netherlands) that translated individual changes in the infrared pattern caused by movements of the animals into activity counts. Sensors were mounted above the home cages and were connected through input ports and an interface to a computer equipped with MED$\mathrm{PC}^{\circledR}$ IV software for data collection (MED associates, St Albans, VT, USA). Activity was expressed in counts per $30 \mathrm{~min}$ (both for the total $24 \mathrm{~h}$ period, the dark period (active period) and the light period (inactive period)). Activity was calculated for each mouse separately. The daily activity measurement for one week was averaged, to reduce the day to day variability $[65,66]$.

\section{Body composition}

Body composition, i.e. lean mass, fat mass and bone mineral density (BMD)/content (BMC) were measured by DEXA scan under general anesthesia using a PIXImus imager (GE Lunar, Madison, WI, USA).

\section{In vivo muscle strength}

In vivo muscle strength was measured as forelimb grip-strength with a calibrated grip strength tester (Panlab, Cornella, Spain) by prompting the mouse to grip the trapeze bar with both forelimbs and pulling the mouse by the tail (proximal to the body) parallel to the orientation of the strain gauge and the trapeze bar. For mean grip strength analyses, a set included five repetitions. Data were calculated as follows: (a) absolute mean grip strength; (b) absolute maximum grip strength, defined as the maximum tension recorded over 5 repetitions.

\section{Ex vivo muscle function}

Contractile characteristics of the $E D L$ muscle were assessed ex vivo, as described previously $[65,67]$. Briefly, muscles were allowed to stabilize in the organ bath (Hugo Sachs Elektronik, March-Hugstetten, Germany), for 30 min in Kreb's Heinselet buffer (mM: $\mathrm{NaCl} 118, \mathrm{KCl} 4.75$, $\mathrm{MgSO}_{4} 1.18, \mathrm{CaCl}_{2} 2.5, \mathrm{KH}_{2} \mathrm{PO}_{4}$ 1.17, $\mathrm{NaHCO}_{3} 24.9$ and glucose 10 ) at $30^{\circ} \mathrm{C}$ and continuously perfused with $95 \% \mathrm{O}_{2}$ and $5 \% \mathrm{CO}_{2}$, after which optimal stimulation current and tension were determined. Subsequently, 
force-frequency characteristics (10-167 Hz, $250 \mathrm{~ms})$ were determined. Isometric force signals of the forcefrequency curve were analyzed for maximal and total force production [65]. After $5 \mathrm{~min}$ of rest and refreshing of the buffer, muscles were subjected to a moderate exercise protocol. Muscles were stimulated $(143 \mathrm{~Hz}, 250$ ms) 100 times. The maximal force production during the first 40 contractions of the exercise protocol was summarized and the ratio between the mean of the first 3 contractions and of the last 3 contractions was used as the fatigue index. Muscle power is defined as maximal force production divided by specific muscle mass (see Figure 2).

\section{Muscle quality index}

Barbat-Artigas $\mathrm{S}$ et al. [2] propose an algorithm to define muscle quality, which we modified for mice as shown in Figure 2. The muscle quality index is based upon muscle mass, strength and power [2]. Therefore, adjusted muscle quality criteria were set for mice based on a 10 months old young reference group ( $n=48$, unpublished data). The reference population used to determine the muscle power/ muscle mass ratio cut-points was composed of 48 C57/B16 mice of 10 months old. Low muscle quality was defined as a muscle power index value below 1 to 2 SDs of our reference population values; whereas poor muscle quality represented a muscle power index of 2 SDs or more (see Table 2).

\section{RT-qPCR method}

Regulation of mitochondrial dynamics was investigated using Reverse Transcription quantitative real-time PCR (RT-qPCR) in EDL. Relative gene expression levels of the seven key genes that function in mitochondrial dynamics were evaluated, namely, mitofusin 1 and 2 ( $M f n 1$ and $M f n 2)$, dynamin-1-like protein (Dnm 1l), fission 1 (Fisl), mitochondrial fission factor $(M f f)$, mitochondrial elongation factor 1 and 2 (Mief1 and Mief2) [68]. Additionally, gene expression modulation of translocase of outer mitochondrial membrane 20 homolog (Tomm20) was studied to evaluate the effect on mitochondrial density. RNA was isolated with the RNeasy Fibrous Tissue Mini Kit (Qiagen) after high speed homogenization with the Tissuelyser II (Qiagen), both according to the manufacturer's protocol. Reverse transcription of RNA to cDNA was performed using the iScript $^{\mathrm{TM}}$ cDNA Synthesis Kit (BioRad), according to the manufacturer's protocol, with an input of $750 \mathrm{ng}$ RNA. RT-qPCRs were performed as we described earlier [69]. Relative expression levels of the genes of interest were normalized by the geometric mean of 3 reference genes according to the $\Delta \Delta \mathrm{Ct}$ method [70]. According to this method, ribosomal protein S15 (Rps 15), hypoxanthine guanine phosphoribosyl transferase (Hprt), and ribosomal protein large P0 (Rplp0) were selected as reference genes. Primers that were used and their sequences are described in Supplementary Table 1.

\section{Biochemical measurements}

Blood samples were taken via cardiac puncture and collected in tubes coated with heparin. Plasma was obtained by centrifugation at $1300 \times \mathrm{g}$ for $10 \mathrm{~min}$ at $4^{\circ} \mathrm{C}$ and stored at $-80^{\circ} \mathrm{C}$. Glucose levels were determined according to the GOD-PAP method [71]. Insulin was analyzed by ELISA (10-1247-01 Mercodia AB, Uppsala, Sweden). Plasma and liver samples for analyses of vitamin $\mathrm{E}$ and $\mathrm{A}$ were mixed with ethanol and centrifuged. The content of retinol and $\alpha$-tocopherol was determined in the supernatant by HPLC, using UV-absorbance for detection of retinol and fluorometric properties for detection of $\alpha$-tocopherol, by comparing with standard solutions [72].

Amino acid concentrations were analyzed in plasma and as free intracellular concentration in muscle by ultra-fast liquid chromatography (UFLC) [73]. For the latter, first the tibialis anterior muscle was cryo-desiccated [74], and muscle supernatants with $2 \%$ PCA were measured for non-protein bound intracellular free amino acid concentrations. Essential amino acids (EAA) were defined as the sum of Histidine, Threonine, Methionine, Tryptophan, Isoleucine, Leucine, Valine, Phenylalanine and Lysine.

\section{Malondialdehyde (MDA)}

After cryo-desiccation of the total liver [74], 10 $\mathrm{mg}$ of the liver and the plantaris muscle was used to perform MDA analysis, a marker for whole-body lipid peroxidation. In short, thiobarbituric (TBA) reacts with MDA at pH3.5. TBA-MDA adduct is separated in a reversed-phase column and quantified by fluorescence detection (ex $515 \mathrm{~nm}$; em $553 \mathrm{~nm}$ ) [75].

\section{Liver glutathione (GSH)}

To determine total glutathione (tGSH) content as a marker for whole-body oxidative stress, another $10 \mathrm{mg}$ of cryo-desiccated liver was used. For tGSH analyses: $0.4 \mathrm{M}$ perchloric acid was added. The samples were placed in an ultrasonic bath for $30 \mathrm{~min}$, vortexed and centrifuged for 10 min at $13.000 \mathrm{rpm}$. The supernatant was diluted 100 times in phosphate-EDTA buffer (0.1 M, pH 7.5). Subsequently, to $40 \mu \mathrm{l}$ sample and $20 \mu \mathrm{l}$ DTNB $(2.38 \mathrm{~g} / 1$ in phosphateEDTA buffer) reagent, $40 \mu \mathrm{l}$ glutathione reductase $(10 \mu \mathrm{l} /$ $\mathrm{ml}$ in phosphate-EDTA buffer) and $100 \mu \mathrm{l}$ NADPH $(0.333$ $\mathrm{g} / \mathrm{l}$ in phosphate-EDTA buffer) were added, and the plate was read immediately. Measurements were performed 
every $21 \mathrm{~s}$ at $405 \mathrm{~nm}$ during $4 \mathrm{~min}$. The maximal velocity was calculated over at least 7 measurements. Maximal velocity for the standards was plotted and a standard curve was constructed. Sample concentration was calculated as $\mathrm{nmol} / \mathrm{mg}$ dry tissue.

\section{Statistical analyses}

All data are expressed as means \pm s.e.m. For randomization and all other experimental outcomes (except for gene expression data), statistical analyses were performed by use of a mixed model with post hoc SIDAKBonferronni testing, including mouse numbers, cohort, diet and age as covariates. To simplify the presentation of the results, after confirmation of no statistical differences between the different diet groups at the beginning of the experiment (prediet) and at the start of the intervention, groups were combined and are displayed as control vs. lowox group. Ex vivo skeletal muscle function data were analyzed by mixed model corrected for growth curve analyses with post hoc LSD. Muscle quality data were analyzed by Fisher's exact tests.

For statistical analyses on the individual gene expression level, data was checked for normality using D'Agostino-Pearson normality test, and if needed logtransformation was applied for normalization. Statistical differences between AOX and TOTAL vs. lowox groups of were analysed by using $t$-testing for normally distributed data, and for not-normally distributed data (even after logtransformation) by the non-parametric Mann-Whitney $U$ test was applied.

To study effects on the process level we applied a novel approach based on Principal Component Analysis (PCA) [76]. In this analysis, a principal component is defined as a mathematically derived combination of genes and their expression characteristics that can be used to describe the process of interest. Here, we combined the gene expression data of all seven genes annotated to mitochondrial dynamics. A number of principal components that are mutually independent can be derived which in combination describe the process under study. Coordinates along the most discriminative principal component were calculated for each sample after PCA transformation. Deviation of respectively the AOX and TOTAL group to the reference group (lowox) was tested for significance by using a $t$-test.

Statistical analyses were performed using SPSS 19.0 (SPSS Benelux, Gorinchem, the Netherlands) and differences were considered significant at a $P$-value below 0.05 .

\section{ACKNOWLEDGMENTS}

The authors thank Jolanda Nagel, Angeline Visscher, Benito Willemsen for assistance with animal care. Miriam van Dijk, Francina Dijk, Annelies Bunschoten, Dorien van Dartel, Stephane Walrand, Marion Jourdan, Sjors Verlaan and Yvette Luiking have no conflict of interest.

\section{CONFLICTS OF INTEREST}

The authors have no relevant conflicts of interest to disclose. Miriam van Dijk, Francina Dijk, Marion Jourdan, Sjors Verlaan and Yvette Luiking are employees at Nutricia Research, Nutricia Adanced Medical Nutrition, Utrecht, The Netherlands.

\section{REFERENCES}

1. Cruz-Jentoft AJ, Baeyens JP, Bauer JM, Boirie Y, Cederholm T, Landi F, Martin FC, Michel JP, Rolland Y, Schneider SM, Topinková E, Vandewoude M and Zamboni M. Sarcopenia: European consensus on definition and diagnosis: Report of the European Working Group on Sarcopenia in Older People. Age and ageing. 2010; 39:412423.

2. Barbat-Artigas S, Rolland Y, Zamboni M and AubertinLeheudre M. How to assess functional status: a new muscle quality index. The journal of nutrition, health \& aging. 2012; 16:67-77.

3. Cuoco A, Callahan DM, Sayers S, Frontera WR, Bean J and Fielding RA. Impact of muscle power and force on gait speed in disabled older men and women. J Gerontol A Biol Sci Med Sci. 2004; 59:1200-1206.

4. Orr R, de Vos NJ, Singh NA, Ross DA, Stavrinos TM and Fiatarone-Singh MA. Power training improves balance in healthy older adults. J Gerontol A Biol Sci Med Sci. 2006; 61:78-85.

5. Foldvari M, Clark M, Laviolette LC, Bernstein MA, Kaliton D, Castaneda C, Pu CT, Hausdorff JM, Fielding RA and Singh MA. Association of muscle power with functional status in community-dwelling elderly women. J Gerontol A Biol Sci Med Sci. 2000; 55:M192-199.

6. Bean JF, Kiely DK, Herman S, Leveille SG, Mizer K, Frontera WR and Fielding RA. The relationship between leg power and physical performance in mobility-limited older people. Journal of the American Geriatrics Society. 2002; 50:461-467.

7. Cuthbertson D, Smith K, Babraj J, Leese G, Waddell T, Atherton P, Wackerhage H, Taylor PM and Rennie MJ. Anabolic signaling deficits underlie amino acid resistance of wasting, aging muscle. Faseb Journal. 2004; 18:422-4.

8. Guillet C, Prod'homme M, Balage M, Gachon P, Giraudet C, Morin L, Grizard J and Boirie Y. Impaired anabolic response of muscle protein synthesis is associated with S6K1 dysregulation in elderly humans. FASEB journal. 2004; 18:1586-1587.

9. Mosoni L, Valluy MC, Serrurier B, Prugnaud J, Obled C, Guezennec CY and Mirand PP. Altered response of protein 
synthesis to nutritional state and endurance training in old rats. The American journal of physiology. 1995; 268:E328335.

10. Arnal MA, Mosoni L, Boirie Y, Houlier ML, Morin L, Verdier E, Ritz P, Antoine JM, Prugnaud J, Beaufrere B and Mirand PP. Protein pulse feeding improves protein retention in elderly women. The American journal of clinical nutrition. 1999; 69:1202-1208.

11. Katsanos CS, Kobayashi H, Sheffield-Moore M, Aarsland A and Wolfe RR. A high proportion of leucine is required for optimal stimulation of the rate of muscle protein synthesis by essential amino acids in the elderly. American journal of physiology Endocrinology and metabolism. 2006; 291:E381-387.

12. Katsanos CS, Kobayashi H, Sheffield-Moore M, Aarsland A and Wolfe RR. Aging is associated with diminished accretion of muscle proteins after the ingestion of a small bolus of essential amino acids. The American journal of clinical nutrition. 2005; 82:1065-1073.

13. Kimball SR and Jefferson LS. Signaling pathways and molecular mechanisms through which branched-chain amino acids mediate translational control of protein synthesis. J Nutr. 2006; 136:227S-231S

14. Dardevet D, Sornet C, Balage M and Grizard J. Stimulation of in vitro rat muscle protein synthesis by leucine decreases with age. The Journal of nutrition. 2000; 130:2630-2635.

15. Norton LE, Wilson GJ, Layman DK, Moulton CJ and Garlick PJ. Leucine content of dietary proteins is a determinant of postprandial skeletal muscle protein synthesis in adult rats. Nutrition \& metabolism. 2012; 9:67.

16. Katsanos CS, Chinkes DL, Paddon-Jones D, Zhang XJ, Aarsland A and Wolfe RR. Whey protein ingestion in elderly persons results in greater muscle protein accrual than ingestion of its constituent essential amino acid content. Nutrition research (New York, NY). 2008; 28:651658 .

17. Boirie Y, Dangin M, Gachon P, Vasson MP, Maubois JL and Beaufrere B. Slow and fast dietary proteins differently modulate postprandial protein accretion. Proceedings of the National Academy of Sciences of the United States of America. 1997; 94:14930-14935.

18. Pennings B. Whey protein stimulates postprandial muscle protein accretion more effectively than do casein and casein hydrolysate in older men. The American journal of clinical nutrition. 2011; epub ahead of print.

19. Siu PM, Pistilli EE and Alway SE. Age-dependent increase in oxidative stress in gastrocnemius muscle with unloading. J Appl Physiol. 2008; 105:1695-1705.

20. Pansarasa O, Bertorelli L, Vecchiet J, Felzani G and Marzatico F. Age-dependent changes of antioxidant activities and markers of free radical damage in human skeletal muscle. Free radical biology \& medicine. 1999; 27:617-622.

21. Gianni P, Jan KJ, Douglas MJ, Stuart PM and Tarnopolsky
MA. Oxidative stress and the mitochondrial theory of aging in human skeletal muscle. Experimental gerontology. 2004; 39:1391-1400.

22. Hamilton ML, Van Remmen H, Drake JA, Yang H, Guo ZM, Kewitt K, Walter CA and Richardson A. Does oxidative damage to DNA increase with age? Proceedings of the National Academy of Sciences of the United States of America. 2001; 98:10469-10474.

23. Cakatay U, Telci A, Kayali R, Tekeli F, Akcay T and Sivas A. Relation of aging with oxidative protein damage parameters in the rat skeletal muscle. Clinical biochemistry. $2003 ; 36: 51-55$.

24. Beckman KB and Ames BN. The free radical theory of aging matures. Physiological reviews. 1998; 78:547-581.

25. Santanasto AJ, Glynn NW, Jubrias SA, Conley KE, Boudreau RM, Amati F, Mackey DC, Simonsick EM, Strotmeyer ES, Coen PM, Goodpaster BH and Newman AB. Skeletal Muscle Mitochondrial Function and Fatigability in Older Adults. J Gerontol A Biol Sci Med Sci. 2014.

26. Johnson ML, Robinson MM and Nair KS. Skeletal muscle aging and the mitochondrion. Trends in endocrinology and metabolism: TEM. 2013; 24:247-256.

27. Ni HM, Williams JA and Ding WX. Mitochondrial dynamics and mitochondrial quality control. Redox biology. 2015; 4:6-13.

28. Marzani B, Balage M, Vénien A, Astruc T, Papet I, Dardevet D and Mosoni L. Antioxidant supplementation restores defective leucine stimulation of protein synthesis in skeletal muscle from old rats. The Journal of nutrition. 2008; 138:2205-2211.

29. Mosoni L, Balage M, Vazeille E, Combaret L, Morand C, Zagol-Ikapitte I, Boutaud O, Marzani B, Papet I and Dardevet D. Antioxidant supplementation had positive effects in old rat muscle, but through better oxidative status in other organs. Nutrition (Burbank, Los Angeles County, Calif). 2010; 26:1157-1162.

30. Sumien N, Forster MJ and Sohal RS. Supplementation with vitamin $\mathrm{E}$ fails to attenuate oxidative damage in aged mice. Experimental gerontology. 2003; 38:699-704.

31. Reznick AZ, Witt E, Matsumoto M and Packer L. Vitamin $\mathrm{E}$ inhibits protein oxidation in skeletal muscle of resting and exercised rats. Biochemical and biophysical research communications. 1992; 189:801-806.

32. Sacheck JM, Milbury PE, Cannon JG, Roubenoff R and Blumberg JB. Effect of vitamin $\mathrm{E}$ and eccentric exercise on selected biomarkers of oxidative stress in young and elderly men. Free radical biology \& medicine. 2003; 34:1575-1588.

33. Dumartheray EW, Krieg MA, Cornuz J, Whittamore DR, Lanham-New SA and Burckhardt P. Energy and nutrient intake of Swiss women aged 75-87 years. Journal of human nutrition and dietetics. 2006; 19(6):431-435.

34. Martins I, Dantas A, Guiomar S and Amorim Cruz JA. Vitamin and mineral intakes in elderly. J Nutr Health 
Aging. 2002; 6:63-65.

35. Lammes E and Akner G. Repeated assessment of energy and nutrient intake in 52 nursing home residents. J Nutr Health Aging. 2006; 10:222-230.

36. Schroder H, Marrugat J, Covas M, Elosua R, Pena A, Weinbrenner T, Fito M, Vidal MA, Masia R and Investigators R. Population dietary habits and physical activity modification with age. European journal of clinical nutrition. 2004; 58:302-311.

37. Ter Borg S, Verlaan S, Hemsworth J, Mijnarends DM, Schols JM, Luiking YC and de Groot LC. Micronutrient intakes and potential inadequacies of community-dwelling older adults: a systematic review. The British journal of nutrition. 2015:1-12.

38. Semba RD, Bartali B, Zhou J, Blaum C, Ko CW and Fried LP. Low serum micronutrient concentrations predict frailty among older women living in the community. J Gerontol A Biol Sci Med Sci. 2006; 61:594-599.

39. Inzitari M, Doets E, Bartali B, Benetou V, Di Bari M, Visser M, Volpato S, Gambassi G, Topinkova E, De Groot L, Salva A, International Association Of G and Geriatrics Task Force For Nutrition In The E. Nutrition in the agerelated disablement process. J Nutr Health Aging. 2011; 15:599-604.

40. Ballak SB, Degens H, de Haan A and Jaspers RT. Aging related changes in determinants of muscle force generating capacity: a comparison of muscle aging in men and male rodents. Ageing research reviews. 2014; 14:43-55.

41. Sayer AA, Robinson SM, Patel HP, Shavlakadze T, Cooper $\mathrm{C}$ and Grounds MD. New horizons in the pathogenesis, diagnosis and management of sarcopenia. Age Ageing. 2013; 42:145-150.

42. Tohma H, El-Shafey AF, Croft K, Shavlakadze T, Grounds $\mathrm{MD}$ and Arthur PG. Protein thiol oxidation does not change in skeletal muscles of aging female mice. Biogerontology. 2014; 15:87-98.

43. Jackson MJ. Interactions between reactive oxygen species generated by contractile activity and aging in skeletal muscle? Antioxidants \& redox signaling. 2013; 19:804-812.

44. Ble A, Cherubini A, Volpato S, Bartali B, Walston JD, Windham BG, Bandinelli S, Lauretani F, Guralnik JM and Ferrucci L. Lower plasma vitamin E levels are associated with the frailty syndrome: the InCHIANTI study. The journals of gerontology Series A, Biological sciences and medical sciences. 2006; 61:278-283.

45. Ryan MJ, Dudash HJ, Docherty M, Geronilla KB, Baker BA, Haff GG, Cutlip RG and Alway SE. Vitamin E and C supplementation reduces oxidative stress, improves antioxidant enzymes and positive muscle work in chronically loaded muscles of aged rats. Experimental gerontology. 2010; 45:882-895.

46. Chaput JP, Lord C, Cloutier M, Aubertin Leheudre M, Goulet ED, Rousseau S, Khalil A and Dionne IJ. Relationship between antioxidant intakes and class I sarcopenia in elderly men and women. The journal of nutrition, health \& aging. 2007; 11:363-369.

47. Reeves PG, Nielsen FH and Fahey GC, Jr. AIN-93 purified diets for laboratory rodents: final report of the American Institute of Nutrition ad hoc writing committee on the reformulation of the AIN-76A rodent diet. J Nutr. 1993; 123:1939-1951.

48. Zangarelli A, Chanseaume E, Morio B, Brugere C, Mosoni L, Rousset P, Giraudet C, Patrac V, Gachon P, Boirie Y and Walrand S. Synergistic effects of caloric restriction with maintained protein intake on skeletal muscle performance in 21-month-old rats: a mitochondria-mediated pathway. FASEB journal. 2006; 20:2439-2450.

49. Barry BK and Carson RG. The consequences of resistance training for movement control in older adults. J Gerontol A Biol Sci Med Sci. 2004; 59:730-754.

50. Richwine AF, Godbout JP, Berg BM, Chen J, Escobar J, Millard DK and Johnson RW. Improved psychomotor performance in aged mice fed diet high in antioxidants is associated with reduced ex vivo brain interleukin-6 production. Brain, behavior, and immunity. 2005; 19:512520.

51. Rederstorff M, Krol A and Lescure A. Understanding the importance of selenium and selenoproteins in muscle function. Cellular and molecular life sciences. 2006; 63:5259.

52. Ryan MJ, Dudash HJ, Docherty M, Geronilla KB, Baker BA, Haff GG, Cutlip RG and Alway SE. Vitamin E and C supplementation reduces oxidative stress, improves antioxidant enzymes and positive muscle work in chronically loaded muscles of aged rats. Experimental gerontology. 2010; 45:882-895.

53. Lee KP, Shin YJ, Cho SC, Lee SM, Bahn YJ, Kim JY, Kwon ES, Jeong do Y, Park SC, Rhee SG, Woo HA and Kwon KS. Peroxiredoxin 3 has a crucial role in the contractile function of skeletal muscle by regulating mitochondrial homeostasis. Free radical biology \& medicine. 2014; 77:298-306.

54. Konopka AR, Suer MK, Wolff CA and Harber MP. Markers of human skeletal muscle mitochondrial biogenesis and quality control: effects of age and aerobic exercise training. J Gerontol A Biol Sci Med Sci. 2014; 69:371-378.

55. Mohamed JS, Wilson JC, Myers MJ, Sisson KJ and Alway SE. Dysregulation of SIRT-1 in aging mice increases skeletal muscle fatigue by a PARP-1-dependent mechanism. Aging (Albany NY). 2014; 6:820-34. doi: 10.18632/ aging.100696.

56. Farnfield MM, Trenerry C, Carey KA and Cameron-Smith D. Plasma amino acid response after ingestion of different whey protein fractions. International journal of food sciences and nutrition. 2008:1-11.

57. Kanda A, Morifuji M, Fukasawa T, Koga J, Kanegae M, Kawanaka K and Higuchi M. Dietary whey protein hydrolysates increase skeletal muscle glycogen levels 
via activation of glycogen synthase in mice. Journal of agricultural and food chemistry. 2012; 60:11403-11408.

58. Pennings B, Groen B, de Lange A, Gijsen AP, Zorenc AH, Senden JM and van Loon LJ. Amino acid absorption and subsequent muscle protein accretion following graded intakes of whey protein in elderly men. American journal of physiology Endocrinology and metabolism. 2012; 302:E992-999.

59. Vianna D, Resende GF, Torres-Leal FL, Pantaleao LC, Donato J, Jr. and Tirapegui J. Long-term leucine supplementation reduces fat mass gain without changing body protein status of aging rats. Nutrition. 2012; 28:182189.

60. Eisen EJ. Results of growth curve analyses in mice and rats. Journal of animal science. 1976; 42:1008-1023.

61. Hamrick MW, Ding KH, Pennington C, Chao YJ, Wu YD, Howard B, Immel D, Borlongan C, McNeil PL, Bollag WB, Curl WW, Yu J and Isales CM. Age-related loss of muscle mass and bone strength in mice is associated with a decline in physical activity and serum leptin. Bone. 2006; 39:845853.

62. Romijn JA, Coyle EF, Sidossis LS, Gastaldelli A, Horowitz JF, Endert E and Wolfe RR. Regulation of endogenous fat and carbohydrate metabolism in relation to exercise intensity and duration. The American journal of physiology. 1993; 265:E380-391.

63. Hermansen L, Hultman E and Saltin B. Muscle glycogen during prolonged severe exercise. Acta physiologica Scandinavica. 1967; 71:129-139.

64. Karlsson J and Saltin B. Diet, muscle glycogen, and endurance performance. J Appl Physiol. 1971; 31:203-206.

65. van Norren K, Kegler D, Argiles JM, Luiking Y, Gorselink M, Laviano A, Arts K, Faber J, Jansen H, van der Beek EM and van Helvoort A. Dietary supplementation with a specific combination of high protein, leucine, and fish oil improves muscle function and daily activity in tumourbearing cachectic mice. British journal of cancer. 2009; 100:713-722.

66. van Norren K, Rusli F, van Dijk M, Lute C, Nagel J, Dijk FJ, Dwarkasing J, Boekschoten MV, Luiking Y, Witkamp RF, Muller M and Steegenga WT. Behavioural changes are a major contributing factor in the reduction of sarcopenia in caloric-restricted ageing mice. J Cachexia Sarcopenia Muscle. 2015; 6:253-268.
67. Gorselink M, Vaessen SFC, Van der Flier LG, Leenders I, Kegler D, Caldenhoven E, Van der Beek E and Van Helvoort A. Mass-dependent decline of skeletal muscle function in cancer cachexia. Muscle Nerve. 2006; 33:691693.

68. Peterson CM, Johannsen DL and Ravussin E. Skeletal muscle mitochondria and aging: a review. Journal of aging research. 2012; 2012:194821.

69. Duivenvoorde LP, van Schothorst EM, Bunschoten A and Keijer J. Dietary restriction of mice on a high-fat diet induces substrate efficiency and improves metabolic health. Journal of molecular endocrinology. 2011; 47:81-97.

70. Livak KJ and Schmittgen TD. Analysis of relative gene expression data using real-time quantitative PCR and the 2(-Delta Delta C(T)) Method. Methods. 2001; 25:402-408.

71. Anjaneyulu M and Chopra K. Quercetin, a bioflavonoid, attenuates thermal hyperalgesia in a mouse model of diabetic neuropathic pain. Progress in neuropsychopharmacology \& biological psychiatry. 2003; 27:1001-1005.

72. Stump DD, Roth EF, Jr. and Gilbert HS. Simultaneous determination by high-performance liquid chromatography of tocopherol isomers, alpha-tocopheryl quinone, and cholesterol in red blood cells and plasma. Journal of chromatography. 1984; 306:371-376.

73. Babu SV, Shareef MM, Shetty AP and Shetty KT. HPLC method for amino acids profile in biological fluids and inborn metabolic disorders of aminoacidopathies. Indian journal of clinical biochemistry. 2002; 17:7-26.

74. Livesey SA, del Campo AA, McDowall AW and Stasny JT. Cryofixation and ultra-low-temperature freeze-drying as a preparative technique for TEM. Journal of microscopy. 1991; 161:205-215.

75. Jackson JR, Ryan MJ and Alway SE. Long-term supplementation with resveratrol alleviates oxidative stress but does not attenuate sarcopenia in aged mice. The journals of gerontology Series A, Biological sciences and medical sciences. 2011; 66:751-764.

76. van Dartel DA, Pennings JL, de la Fonteyne LJ, Brauers KJ, Claessen S, van Delft JH, Kleinjans JC and Piersma AH. Concentration-dependent gene expression responses to flusilazole in embryonic stem cell differentiation cultures. Toxicology and applied pharmacology. 2011; 251:110-118. 